\title{
Evaluasi Perlintasan Sebidang Jalan Rel Dengan Jalan Raya Di Kota Semarang
}

\author{
(Studi Kasus Perlintasan Sebidang Di Jalan Sadewa, Jembawan Raya Dan Stasiun Jrakah)
}

\author{
Gita Mustika Dewi Kelo', Gloryani Fransiska N Jehudu², \\ Rudatin Ruktiningsih ${ }^{3}$ \\ email: 1'gitamdkelo@gmail.com, ${ }^{2}$ rianyjehudu60@gmail.com
}

Program Studi Teknik Sipil, Fakultas Teknik, Unika Soegijapranata, Semarang, Universitas Katolik Soegijapranata; Jl. Pawiyatan Luhur IV/1 Bendan Dhuwur Semarang 50234, 024-8441555

\begin{abstract}
Abstrak
Perkembangan sarana transportasi membentuk pertemuan antara jalan raya dengan dengan jalan rel. Masalah yang sering timbul akibat pertemuan kedua sarana transportasi ini adalah kecelakaan dan kemacetan.Oleh karena itu dibutuhan peranan sistem kontrol pada perlintasan sebidang. Perlintasan sebidang adalah persilangan antara jalan raya yang berpotongan dengan jalan rel kereta api pada ketinggian yang sama. Pembuatan perlintasan sebidang harus memenuhi Peraturan Dirjen Perhubungan SK 770 tahun 2005. PadaJalan Sadewa, Jembawan Raya, dan Jalan Stasiun Jrakah terdapat jalur kereta double track dengan perlintasan sebidang tanpa pintu. Metode penelitian yang digunakan adalah metode survei, antara lain survei volume lalu lintas, survei frekuensi kereta api, survei sarana dan prasarana, survei spot speed, menghitung panjang antrian dan menghitung tundaan. Berdasarkan hasil analisis ketentuan teknis perlintasan sebidang perlintasan sadewa $(308.307,49$ smpk), perlintasan stasiunjrakah (216.666,39 smpk) dan perlintasan jembawan raya (66.903,09 smpk) tidak memenuhi standar teknis perlintasan sebidang $(<35.000$ smpk $)$ sehingga sebaiknya ditingkatkan menjadi perlintasan tak sebidang. Meskipun dari analisis panjang antrian dan tundaan, kapasitas jalan yang ada masih memenuhi syarat ( $D S<0,75)$, namun berdasarkan analisis volume , kapasitas jalan pada Jalan Sadewa, Stasiun Jrakah sudah tidak memenuhi syarat (DS $>0,75)$ sehingga perlu penanganan ulang yaitu pelebaran jalan pada Jalan Sadewa dan Jalan Stasiun Jrakah.
\end{abstract}

Kata kunci : Perlintasan Sebidang, Jalan, Kapasitas,Volume, Panjang Antrian,Tundaan

\begin{abstract}
Development in transportation can form crossing between road and railroad, between these two tranportation facilities some problem could happen, which are accident and traffic. Therefore control management will be necessary. Level crossing is an intersection where a railway line crosses a road at the same level. In Indonesia, there's regulation about level crossing which is SK 770 tahun 2005. In sadewa street, jembawan raya street and stasiun jrakah street there's double track railway and level crossing without barrier. To evaluate level crossing, this research used survei method, such as traffic volume survei, train frequency survei, survei level crossing facilities, spot speed survei, queque length, and delayed time. Based on analysis on level crossing technical regulations, level crossing in sadewa street (308.307,49 smpk), jembawan raya street (66.903,09 smpk) and stasiun jrakah (216.666,39 smpk) street not fullfilling level crossing standart regulations (<35.000 smpk) and it should be changed to flyover or underpass. Eventho from queque and stopped delay analysis road capacity still capable to handle the traffic $(D S<0,75)$, but based on volume analysis road capacity in
\end{abstract}


sadewa street and stasiun jrakah street not capable enough to handle the traffic $(D S>0,75)$ so reobservation to road condition will be necessary.

Keywords: Level crossing, railway, road, queque, stopped delay, road capacity, volume

\section{PENDAHULUAN}

Perkembangan sarana transportasi membentuk pertemuan antara jalan raya dengan dengan jalan rel. Masalah yang sering timbul akibat pertemuan kedua sarana transportasi ini adalah kecelakaan dan kemacetan.Beberapa faktor penyebab terjadinya kecelakaan antara lain rusaknya jalan pada perlintasan, infrastruktur yang tidak lengkap, geometrik jalur kereta api dan jalan raya tidak sesuai, dan kelalaian manusia. Sedangkan faktor penyebab kemacetan adalah kendaraan yang mengalami tundaan di perlintasan sebidang.Oleh karena itu dibutuhan peranan sistem kontrol untuk mencegah terjadinya kemacetan maupun kemacetan pada perlintasan sebidang.

Pada perlintasan sebidang ada beberapa perlintasan sebidang yang memiliki pintu dan yang tidak memiliki pintu hal inilah yang akan mengakibatkan berbagai macam masalah yang dapat terjadi dalam perlintasan sebidang. Ada beberapa peraturan perudang-undangan yang harus dipenuhi dalam perlintasan sebidang dalam hal ini kelancaran perjalanan kereta api dan lalu lintas jalan perpotongan sebidang harus memenuhi persyaratan memenuhi pandangan bebas masinis dan pengguna lalu lintas, dilengkapi rambu-rambu lalu lintas jalan dan peralatan persinyalan

Berdasarkan Undang-undang No. 23 Tahun 2007 Tentang Perkeretaapian. Dalam Pasal 124 disebutkan bahwa pada perpotongan sebidang antara jalur kereta api dan jalan, pemakai jalan wajib mendahulukan perjalanan kereta api.
Dengan adanya perlintasan, maka pergerakan arus lalu lintas kendaraan menjadi terganggu ketika kereta api melintas. Hal ini akan mengakibatkan terjadinya tundaan dan panjang antrian kendaraan

Perlintasan sebidang di Jalan Sadewa, Jembawan Raya, dan Jalan Stasiun jrakah dipilih sebagai lokasi penelitian dikarenakan jalan-jalan ini merupakan jalan-jalan kota yang juga merupakan jalan menuju pusat perbelanjaan, jalur pekerja menuju kantor, dan pelajar menuju sekolah atau universitas. Meskipun jalur kereta sudah double track, namun perlintasan tersebut masih belum menggunakan pintu, hal ini dapat berdampak pada keselamatan lalu lintas. Oleh karena itu maka dilakukan evaluasi perlintasan sebidang dengan menggunakan Peraturan Direktur Jendral Perhubungan Darat tentang pedoman teknis perlintasan sebidang antara jalan raya dan jalur kereta api serta hubungan antara volume, kecepatan, tundaan dan panjang antrian terhadap kapasitas jalan pada perlintasan sebidang.

\section{TINJAUAN PUSTAKA}

UU No.14 Tahun 1992 tentang Lalu Lintas dan Angkutan Jalan pasal 2 ayat 1 menyatakan bahwa keselamatan, kelancaran, dan ketertiban lalu lintas dan angkutan jalan ditetapkan ketentuanketentuan mengenai rekayasa dan manajemen lalu lintas.

Menurut Direktorat Jendral Bina Marga (2012), pentingnya perhitungan 
jarak pandang bagi keselamatan lalu lintas dikarenakan manusia membutuhkan waktu untuk bereaksi dan membutuhkan jarak untuk mengambil tindakan menghindar, semakin cepat mereka melaju saat melihat objek pertama kali, semakin besar jarak berhenti yang dibutuhkan. Pada umumnya, waktu reaksi pengendara atau pengemudi adalah 2 detik. Dengan mengetahui jarak pandang aman pada perlintasan kereta api, maka dapat diketahui kecepatan kendaraan yang aman untuk melintasi suatu perlintasan.

Berdasarkan hukum, perlintasan dibagi menjadi dua jenis yaitu perlintasan resmi dan tidak resmi.Perlintasan resmi adalah perlintasan sebidang yang telah sesuai dengan syarat - syarat dan ketentuan hukum sesuai Undang - Undang 23 Tahun 2007 tentang Perkeretaapian. Perlintasan sebidang resmi dilengkapi dengan palang pintu perlintasan, rambu lalu lintas, rambu peringatan, rambu stop, marka jalan lambang dan tulisan berupa silang dan huruf KA, Isyarat lampu, Isyarat suara serta adanya penjagaan oleh pegawai operator prasarana perkeretaapian. Sedangkan perlintasan tidak resmi adalah perlintasan sebidang yang belum/tidak memiliki syarat - syarat dan ketentuan hukum sesuai Undang - Undang 23 Tahun 2007 tentang Perkeretaapian.Pada perlintasan tidak resmi, biasanya dilengkapi dengan palang dari besi atau kayu ataupun tanpa palang.

Peraturan Pemerintah no 56 Tahun 2009, perpotongan sebidang hanya dapat dilakukan apabila letak geografis yang tidak memungkinkan membangun perpotongan tidak sebidang, tidak membahayakan dan mengganggu kelancaran operasi kereta api dan lalu lintas jalan dan pada jalan jalur tunggal dengan frekuensi dengan kecepatan kereta api rendah untuk menjamin keselamatan dan kelancaran perjalanan kereta api dan lal lintas jalan perpotongan sebidang harus memenuhi persyaratan memenuhi pandangan bebas masinis dan pengguna lalu lintas, dilengkapi rambu-rambu lalu lintas jalan dan peralatan persinyalan, dibatasi hanya pada jalan kelas 3, memenuhi standar spesifikasi teknis perpotongan sebidang.

Berdasarkan Peraturan Direktorat Jenderal Perhubungan Darat, Pedoman Teknis Perlintasan Sebidang Antara Jalan Raya dengan Jalan Kereta Api yang dikeluarkan oleh Dinas Perhubungan tahun 2005 maupun Perencanaan Perlintasan Jalan dengan Jalan Kereta Api oleh Departemen Pemukiman dan Prasarana Wilayah tahun 2004, ada 2 ketentuan dalam perencanaan perlintasan sebidang yaitu:

1. Ketentuan Umum

Dalam pedoman perlintasan jalan dengan jalur kereta api harus memperhatikan aspek-aspek sebagai berikut:

a. Keselamatan lalu lintas, dimana kereta api mempunyai prioritas utama.

b. Pandangan bebas pemakai jalan.

c. Kepentingan pejalan kaki

d. Drainase jalan.

e. Kepentingan penyandang cacat.

f. Desain yang ramah lingkungan.

2. Ketentuan Teknis

a. Geometrik pada perlintasan sebidang (sarana dan prasarana, klasifikasi, fungsi jalan, potongan melintang dan daerah/ ruang bebas).

b. Pengaturan lalu lintas.

c. Tipe perkerasan pada perlintasan sebidang.

Persyaratan penyelenggaraan persilangan sebidang antara jalan dengan kereta api mengacu kepada Peraturan Direktur Jenderal Perhubungan Darat 
Nomor

SK.770/KA.401/DRJD/2005

tentang Pedoman Teknis Perlintasan

Sebidang Antara Jalan dengan Jalur Kereta

Api. Didalam peraturan tersebut serta mengacu kepada peraturan perundangan yang lebih tinggi, maka perlintasan antara jalan dengan jalur kereta api dibuat dengan prinsip tidak sebidang.

1. Perhitungan jarak pandang

Persamaan dasar hubungan antara jarak pandang dengan kecepatan kendaraandan kereta

$$
\begin{aligned}
d_{H} & =0,28 V_{V} t+\frac{V_{V^{2}}}{254 f}+D+d_{c} \\
d_{T} & =\frac{V_{T}}{V_{V}}\left[\frac{V_{V^{2}}}{254 f}+2 D+L+W\right]
\end{aligned}
$$

Keterangan:

$\mathrm{dH}$ : Jarak pandang terhadap jalan raya yang menyebabkan kendaraan dapat mencapai kecepatan VV untuk melintasi rel dengan aman meskipun kereta sudah terlihat pada jarak dT dari perlintasan, atau jarak untuk menghentikan kendaraan dengan aman tanpa melanggar batas perlintasan

dT : Jarak pandang terhadap jalan untuk melakukan manuver seperti dideskripsikan $\mathrm{dH}$

VV : kecepatan kendaraan $(\mathrm{km} / \mathrm{jam})$

VT : kecepatan kereta $(\mathrm{km} / \mathrm{jam})$

t : waktu presepsi(reaksi)

$\mathrm{f}$ : koefisien gesek, menurut AASHTO nilai

$\mathrm{f}=-0,00065 \mathrm{Vv}+0.192$ untuk $\mathrm{Vv} \leq 80 \mathrm{~km} / \mathrm{jam}$ $\mathrm{f}=-0.00125 \mathrm{Vv}+0.24$ untu $\mathrm{kVv}>80 \mathrm{~km} / \mathrm{jam}$

D : jarak dari garis stop atau dari bagian depan kendaraan terhadap rel terdekat

de : jarak dari pengemudi terhadap bagian depan kendaraan

L : panjang kendaraan

W : jarak antara rel-relterluar
2. Kapasitas $\mathrm{C}=\mathrm{CO} \times \mathrm{FC}_{\mathrm{W}} \times \mathrm{FC}_{\mathrm{SP}} \times \mathrm{FC}_{\mathrm{SF}} \times \mathrm{FC}_{\mathrm{CS}}$

Dimana,

$$
\begin{aligned}
\mathrm{C}= & \text { Kapasitas }(\mathrm{smp} / \mathrm{jam}) \\
\mathrm{Co}= & \text { Kapasitas dasar }(\mathrm{smp} / \mathrm{jam}) \\
\mathrm{FCW}= & \text { Faktor penyesuaian lebar } \\
& \text { jalur lalu }- \text { lintas } \\
\mathrm{FCSP}= & \text { Faktor penyesuaian } \\
& \text { pemisahan arah } \\
\mathrm{FCSF}= & \text { Faktor penyusaian hambatan } \\
& \text { samping } \\
\mathrm{FCCS}= & \text { Faktor penyesuaian ukuran } \\
& \text { kota }
\end{aligned}
$$

3. Derajat Kejenuhan

$$
D S=\frac{Q}{C}
$$

Keterangan :

$$
\begin{array}{ll}
\mathrm{DS} & =\text { Derajat kejenuhan } \\
\mathrm{Q} & =\text { Arus lalu lintas }(\mathrm{smp} / \mathrm{jam}) \\
\mathrm{C} & =\text { Kapasitas }(\mathrm{smp} / \mathrm{jam})
\end{array}
$$

4. Proyeksi Arus Lalu Lintas

$$
\text { Pn }=\text { Po } \times(1+i \%)^{n}
$$

Dimana :

$$
\begin{array}{rlr}
\mathrm{Pn}= & \text { Jumlah Kendaraan } & \text { Pada } \\
& \text { Tahun Proyeksi } \\
\mathrm{P} & = & \text { Jumlah Kendaraan Pada } \\
& \text { Tahun Eksisting } \\
\mathrm{I} & = & \text { Angka pertumbuhan } \\
\mathrm{N} & = & \text { Jumlah tahun }
\end{array}
$$

\section{METODE PENELITIAN}

Pada penelitian ini mengambil objek Perlintasan Sebidang di Kota Semarang. Lokasi yang terpilih dalam penelitian ini terdapat di tiga lokasi perlintasan sebidang yang akan diteliti, sebagai berikut : 
1. Perlintasan Sebidang di Jalan Sadewa

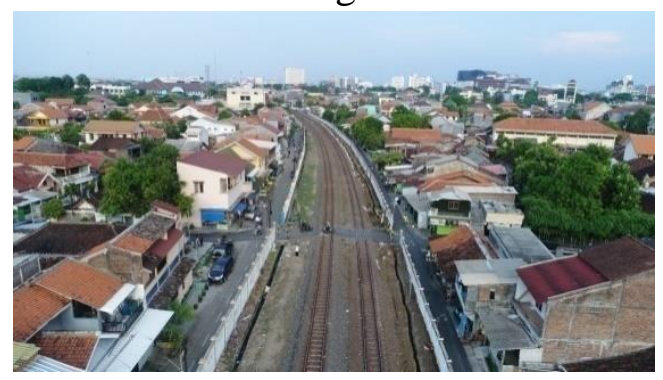

Gambar 4.1 Lokasi Penelitian di Jalan Sadewa

(Sumber : Dokumentasi Pribadi,2018)

2. Perlintasan Sebidang di Jalan membawan Raya

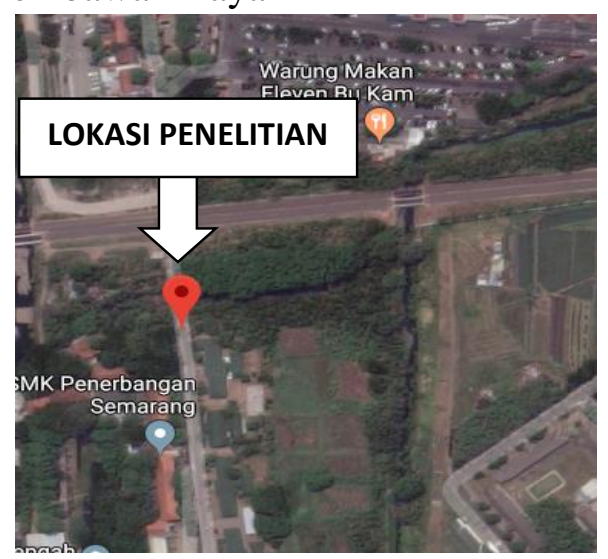

Gambar 4.2 Lokasi Penelitian di Jalan Jembawan Raya (Sumber : Google Maps,2018)

3. Perlintasan Sebidang di Jalan Stasiun Jrakah

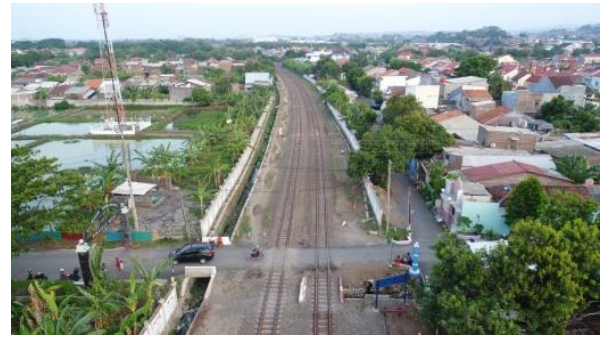

Gambar 4.3 Lokasi Penelitian di Jalan Stasiun Jrakah

(Sumber : Dokumentasi Pribadi,2018)
Data yang dibutuhkan dalam penelitian terdiri dari data primer dan data sekunder.

Data primer didapat dengan melakukan survei yang menghasilkan data yang terdiri dari data volume lalu lintas, data kecepatan lalu lintas, data tundaang, data panjang antrian dan data kelengkapan prasarana di perlintasan sebidang.

1. Survei Volume Lalu Lintas

LHR yang dihitung yaitu gerak kendaraan yang melewati perlintasan sebidang. Proses pendataan volume lalu lintas dilakukan secara manual dengan menggunakan alat bantu aplikasi "thing counter". Setiap kendaraan yang lewat dikelompokkan sesuai jenis kendaraan.Survei dilakukan selama 1 minggu dengan interval pendataan setiap 15 menit.Kendaraan yang disurvei pada penelietian ini dibagi dalam 12 moda angkutan. Lembar form survei diiisi berdasarkan jenis kendaraaannya. Lalu lintas yang melewati perlitasan sebidang terdiri dari berbagai jenis kendaraan, oleh karena itu untuk menyeragamkan jenis kendaraan yang berbeda-beda maka masing-masing jenis kendaraaan dikalikan dengan faktor SMP.

2. Survei Kecepatan Lalu Lintas

Pada penelitian ini, kecepatan yang akan diteliti adalah kecepatan spot speed saat kendaraan melewati perlintasan kereta api. Pada pengamatan ini, sampel yang diambil adalah 30 untuk setiap jenis kendaraan dengan interval waktu 15 menit.

3. Survei Tundaan serta Panjang Antrian Untuk mengetahui lamanya tundaan yang terjadi saat kereta api melintas, pengamat mencatat waktu saat kereta melintas. Sedangkan untuk mendapatkan data panjang antrian dilakukan dengan mengukur panjang 
antrian menggunakan meteran danmenghitung jenis serta jumlah kendaraan yang mengalami tundaan.

4. Survei Kondisi Perlintasan Sebidang Sesuai SK 770 Tahun 2005

Data yang dapat diperoleh dari survei ini adalah Informasi tentang perlintasan sebidang di lapangan.Data yang diperoleh dicatat dalam formulir.Sedangkan data sekunder didapat dari instansi terkait yang menghasilkan data yang terdiri dari terdiri dari frekuensi kereta api dari PT.KAI serta data geometri jalan dari Dinas Pekerjaan Umum Kota Semarang.

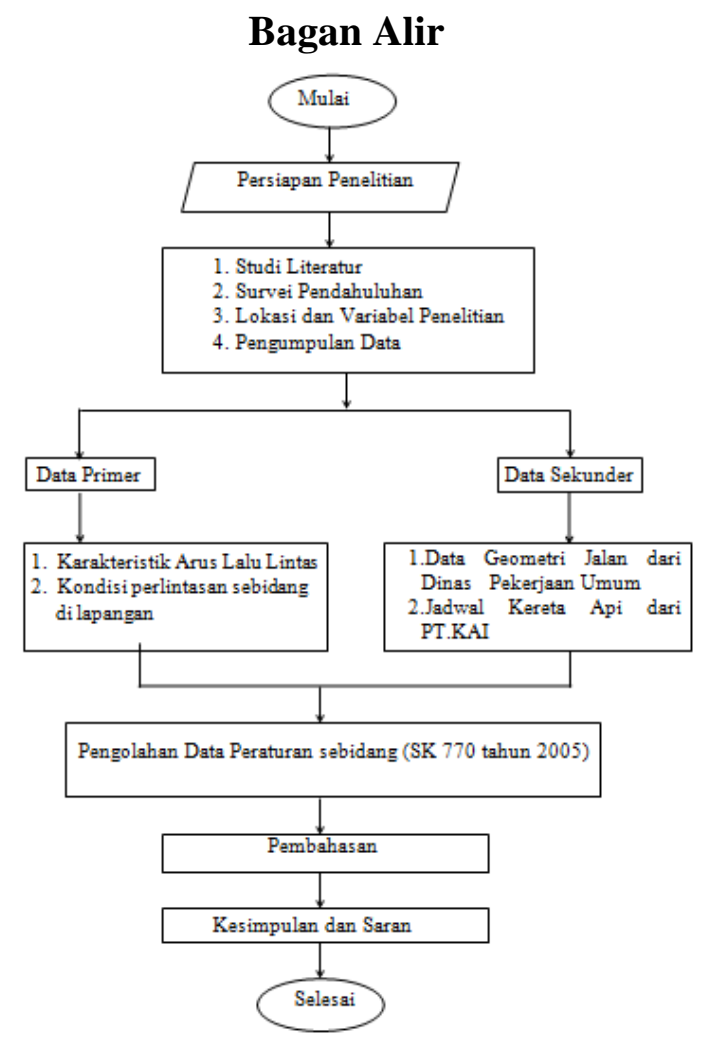

Gambar 4.4 Bagan Alir
4. HASIL DAN PEMBAHASAN

1. Volume Perlintasan Sadewa

Tabel 4.1 Tabel Perhitungan LHR

\begin{tabular}{cccc}
\hline & $\begin{array}{c}\text { Survey } \\
\text { 11 Jam }\end{array}$ & $\begin{array}{c}\text { Rata- } \\
\text { Rata }\end{array}$ & $\begin{array}{c}24 \\
\text { Jam }\end{array}$ \\
\hline Totak & 7320 & 665 & $\begin{array}{c}15971 . \\
03\end{array}$ \\
Kendaraan & & & 03145.9 \\
Volume & 1441.9 & 131.08 & 3 \\
Kendaaran & 1 & & 9 \\
\hline LHR x & & 308307.49 & \\
Frekuensi & & & \\
Kereta Api & & & \\
\hline
\end{tabular}

(Sumber : Hasil Analisis,2018)

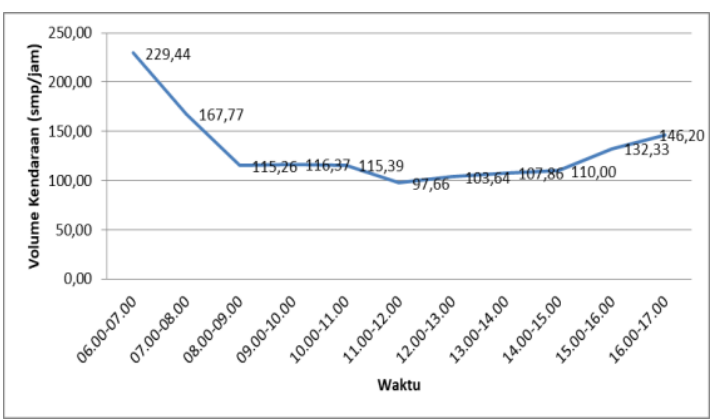

Gambar 4.5 Diagram garis hubungan volume kendaraan dan waktu pada perlintasan sadewa

(Sumber : Hasil Analisis, 2018)

2.Volume Perlintasan Stasiun Jrakah

Tabel 4.2 Tabel Perhitungan LHR

\begin{tabular}{cccc}
\hline & $\begin{array}{c}\text { Survey } \\
\text { 11 Jam }\end{array}$ & $\begin{array}{c}\text { Rata- } \\
\text { Rata }\end{array}$ & 24 Jam \\
\hline Totak & 5176 & 471 & $\begin{array}{c}11292 . \\
47\end{array}$ \\
Kendaraan & & & 2519.3 \\
\hline Volume & 1154.7 & 104.97 & 8 \\
Kendaaran & 1 & & \\
\hline LH x & & 216666.39 & \\
Frekuensi & & & \\
Kereta Api & & & \\
\hline
\end{tabular}

(sumber : Hasil Analisis,2018) 


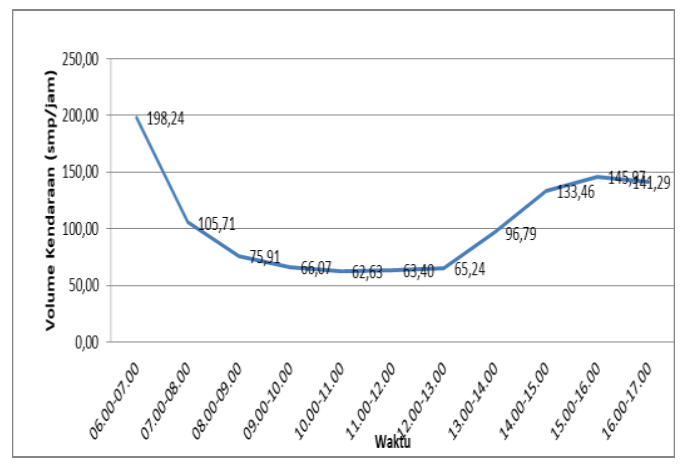

Gambar 4.6 Diagram garis hubungan volume kendaraan dan waktu pada perlintasan stasiun jrakah (Sumber : Hasil Survei, 2018)

3. Volume Perlintasan Jembawan Raya Tabel 4.3 Tabel Perhitungan LHR

\begin{tabular}{cccc}
\hline & $\begin{array}{c}\text { Survey } \\
\text { 11 Jam }\end{array}$ & $\begin{array}{c}\text { Rata- } \\
\text { Rata }\end{array}$ & 24 Jam \\
\hline Totak & $\begin{array}{c}1790.4 \\
162.77\end{array}$ & $\begin{array}{c}3906.3 \\
9\end{array}$ \\
Kendaraan & 3 & & 777.94 \\
\hline Volume & 356.56 & 32.41 & \\
Kendaaran & & & \\
\hline LH x & & 66903.09 & \\
Frekuensi & & & \\
Kereta Api & & & \\
\hline
\end{tabular}

(Sumber: Hasil Analisis, 2018)

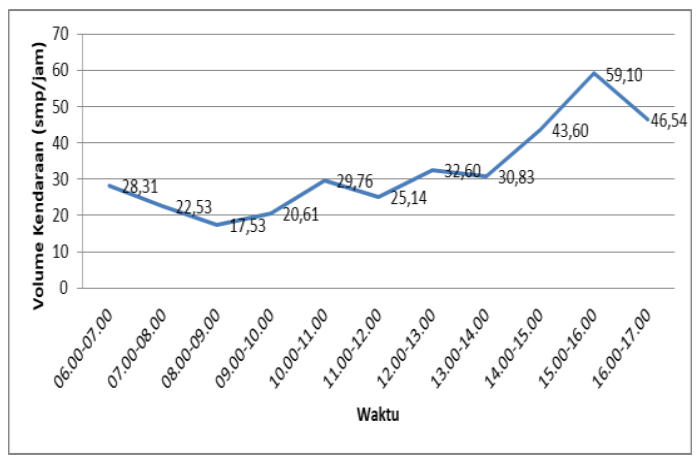

Gambar 4.7 Diagram garis Hubungan antara Volume Kendaraan dan Waktu pada Perlintasan Jembawan Raya (Sumber : Hasil Analisis ,2018)

\section{Spot Speed Perlintasan Sadewa}

Tabel 4.4 Tabel Rekap Spot Speed Perlintasan Sadewa

\begin{tabular}{llll}
\hline No & $\begin{array}{l}\text { Jenis } \\
\text { Kendaraan }\end{array}$ & $\begin{array}{l}\text { Waktu } \\
(\mathbf{d e t})\end{array}$ & $\begin{array}{l}\mathbf{V} \\
(\mathbf{k m} / \mathbf{j a m})\end{array}$ \\
\hline Senin & $\begin{array}{l}\text { Sepeda } \\
\text { Motor }\end{array}$ & 7,56 & 8,37 \\
\hline Selasa & $\begin{array}{l}\text { Sepeda } \\
\text { Motor }\end{array}$ & 6,96 & 9,10 \\
\hline Rabu & $\begin{array}{l}\text { Sepeda } \\
\text { Motor }\end{array}$ & 7,72 & 8,20 \\
\hline Kamis & $\begin{array}{l}\text { Sepeda } \\
\text { Motor }\end{array}$ & 7,88 & 8,04 \\
\hline Jumat & $\begin{array}{l}\text { Sepeda } \\
\text { Motor }\end{array}$ & 8,16 & 7,76 \\
\hline Sabtu & $\begin{array}{l}\text { Sepeda } \\
\text { Motor }\end{array}$ & 7,94 & 7,97 \\
\hline Minggu & $\begin{array}{l}\text { Sepeda } \\
\text { Motor }\end{array}$ & 7,68 & 8,24 \\
\hline
\end{tabular}

(Sumber : Hasil Survei, 2018)

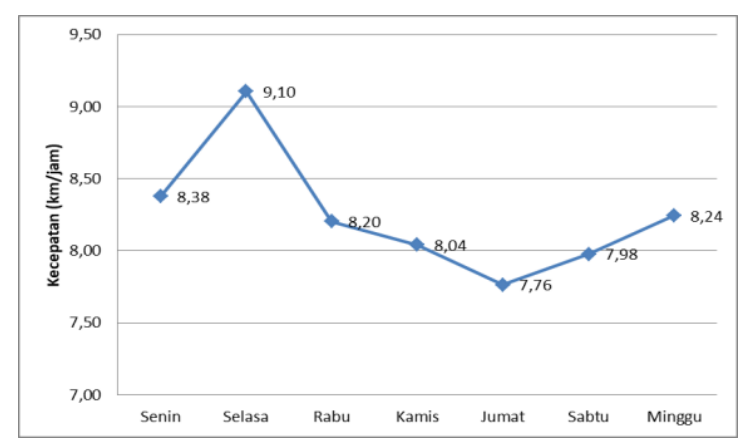

Gambar 4.8 Diagram garis spot speed pada perlintasan sadewa (Sumber : Hasil Survei, 2018) 
5. Spot Speed Perlintasan Stasiun Jrakah

Tabel 4.5 Tabel Rekap Spot Speed Perlintasan Stasiun Jrakah

\begin{tabular}{llll}
\hline No & $\begin{array}{l}\text { Jenis } \\
\text { Kendaraan }\end{array}$ & $\begin{array}{l}\text { Waktu } \\
(\mathbf{d e t})\end{array}$ & $\begin{array}{l}\mathbf{V} \\
(\mathbf{k m} / \mathbf{j a m})\end{array}$ \\
\hline \multirow{2}{*}{1} & $\begin{array}{l}\text { Sepeda } \\
\text { Motor }\end{array}$ & 6,84 & 9,27 \\
\hline 2 & Mobil & 10,22 & 6,20 \\
\hline 3 & MPU & 12,50 & 5,07 \\
\hline 4 & Pick Up & 11,34 & 5,58 \\
\hline 5 & Truk & 10,56 & 6,00 \\
\hline 6 & Sedan & 9,94 & 6,37 \\
\hline 7 & Truk Berat & 18,65 & 3,40 \\
\hline
\end{tabular}

(Sumber : Hasil Survei, 2018)

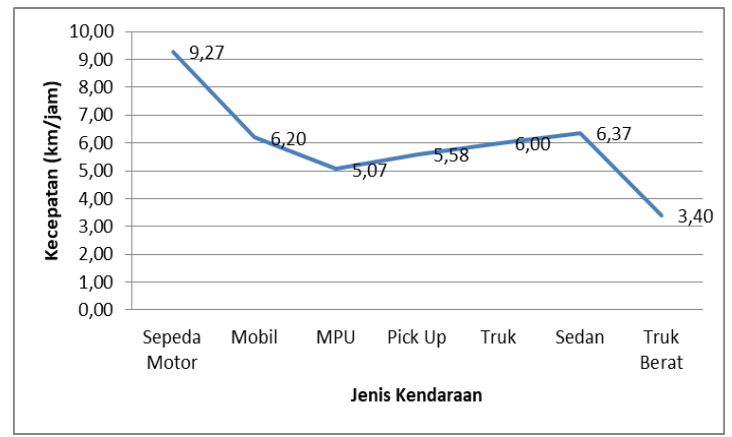

Gambar 4.9 Diagram garis spot speed pada perlintasan stasiun jrakah (Sumber : Hasil Survei, 2018)

\section{Spot Speed Perlintasan Jembawan Raya}

Tabel 4.6 Tabel Rekap Spot Speed Perlintasan Jembawan Raya

\begin{tabular}{cccc}
\hline No & $\begin{array}{c}\text { Jenis } \\
\text { Kendaraan }\end{array}$ & $\begin{array}{c}\text { Waktu } \\
\text { (det) }\end{array}$ & $\begin{array}{c}\text { V } \\
\text { (km/jam) }\end{array}$ \\
\hline 1 & Sepeda Motor & 7,46 & 8,50 \\
\hline 2 & Mobil & 8,36 & 7,58 \\
\hline 3 & Pick Up & 9,43 & 6,72 \\
\hline
\end{tabular}

(Sumber : Hasil Survei, 2018)

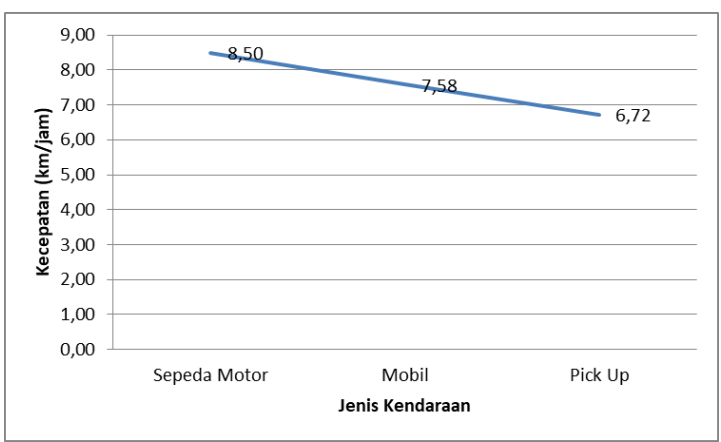

Gambar 4.10 Diagram garis spot speed pada perlintasan jembawan raya (Sumber : Hasil Survei, 2018)

7. Kapasitas jalan sadewa, stasiun jrakah dan jembawan raya

Tabel 4.7 Rekap perhitungan kapasitas

\begin{tabular}{||l|c|c|c|c|c|c||}
\hline \hline Perlintasan & $\begin{array}{c}\text { CO } \\
\text { (smp/jam) }\end{array}$ & FCw & FCsp & FCsf & FCcs & C(smp/jam) \\
\hline Sadewa & 2900 & 0,35 & 1 & 1 & 1 & 1015 \\
\hline $\begin{array}{l}\text { Stasiun } \\
\text { Jrakah }\end{array}$ & 2900 & 0,39 & 1 & 1 & 1 & 1131 \\
\hline $\begin{array}{l}\text { Jembawan } \\
\text { Raya }\end{array}$ & 2900 & 0,44 & 1 & 1 & 1 & 1276 \\
\hline
\end{tabular}

(sumber : Hasil Analisis, 2018)

\section{Analisis Ketentuan Teknis Perlintasan Sebidang}

Dalam menganalisis ketentuan teknis perlintasan sebidang, parameter yang ada di lapangan dibandingkan dengan peraturan Direktur Jenderal Perhubungan Darat Nomor 770 tahun 2005 tentang Pedoman Teknis Perlintasan Sebidang antara Jalan dengan Jalur kereta Api dan Peraturan Pemerintah 56 tahun 2009.

a. Analisis Persyaratan Perlintasan Sebidang pada Perlintasan Sebidang Sadewa 


\begin{tabular}{|c|c|c|c|}
\hline No & Persyaratan perlintasan sebidang & Perlintasan kereta api sadewa & \\
\hline 1 & $\begin{array}{l}\text { Selang waktu antara kereta api satu dengan kereta } \\
\text { api berikutnya (Head way) yang melintas pada } \\
\text { lokasi tersebut rata-rata selurang-kurangnya } 6 \\
\text { (enam) menit pada walktu sibuk (peak) }\end{array}$ & $\begin{array}{l}\text { Selang waktu antara kereta api satu } \\
\text { dengan kereta api berikutnya (Head } \\
\text { way) yang melintas pada perlintasan } \\
\text { Sadewa adalah } 7 \text { menit }\end{array}$ & $\sqrt{ }$ \\
\hline 2 & $\begin{array}{l}\text { Jarak perlintasan yang satu dengan yang lainnya } \\
\text { pada satu jalur kereta api tidak kurang dari } 800 \\
\text { meter, }\end{array}$ & $\begin{array}{l}\text { Jarak perlintasan terdekat adalah } 450 \\
\text { meter }\end{array}$ & $\times$ \\
\hline 3 & $\begin{array}{l}\text { Tidak terletak pada lenghungan jalan kereta api } \\
\text { atav tikungan jalan; }\end{array}$ & Berada pada kondisi jalan lurus & $\sqrt{ }$ \\
\hline 4 & $\begin{array}{l}\text { Terdapat kondisi lingkungan yang } \\
\text { memungkinkan pandangan bagi masinis kereta } \\
\text { api dari as perlintasan dan bagi pengemvdi } \\
\text { kendaran bermotor, }\end{array}$ & $\begin{array}{l}\text { Tidak ada bangunan ataupun pohon } \\
\text { yang menghalangi jaral; pandang } \\
\text { pengguna jalan }\end{array}$ & $\sqrt{ }$ \\
\hline 5 & Jalan yang melintas adalah jalan Kelas III & $\begin{array}{l}\text { Jalan sadewa termasulk ke dalam kelas } \\
\text { III }\end{array}$ & $\sqrt{ }$ \\
\hline No & Persyaratan prasarana jalan dan liereta api & \multicolumn{2}{|l|}{$\begin{array}{c}\text { Prasarana jalan dan liereta api pada } \\
\text { perlintasan sadewa }\end{array}$} \\
\hline 1 & Jalan Kelas III & \begin{tabular}{|l|}
$\begin{array}{l}\text { Jalan Sadewa termasuk ke dalam kelas } \\
\text { iII }\end{array}$ \\
\end{tabular} & $\sqrt{ }$ \\
\hline 2 & 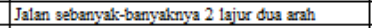 & Jalan terdiri dari 2 lajur 2 arah & v \\
\hline 3 & $\begin{array}{l}\text { Tidak pada tikungan jalan dan/atas alinement } \\
\text { horizontal yang memiliki radivs sekurang- } \\
\text { kurangnya } 500 \mathrm{~m} \text { : }\end{array}$ & Berada pada kondisi jalan lunus & $\sqrt{ }$ \\
\hline 4 & $\begin{array}{l}\text { Tinglkat kelandaian kurang dari } 5 \text { (lima) persen } \\
\text { dari titik terluar ialan rel: }\end{array}$ & Memiliki ketinggian yang berbeda & $\sqrt{ }$ \\
\hline 5 & Wajib dilenglapi Rambu peringatan & Rambu peringatan berupa kata - kata & ' $x$ \\
\hline 6 & Wajib dilengkapi rambu larangan & Terdapat rambu andreas cross & $2 \times$ \\
\hline 7 & $\begin{array}{l}\text { Wajib dilengkapi perlengkapan jalan bervpa } \\
\text { marka jalan }\end{array}$ & Tidak terdapat marka jalan & ' $x$ \\
\hline 8 & $\begin{array}{l}\text { Wajib dilengkapi dengan isyarat lampu dan } \\
\text { suara }\end{array}$ & Terdopat isyarat lampu dan suara & $\sqrt{ }$ \\
\hline No & Penentuan Perlintasan Sebidang & \multicolumn{2}{|l|}{ Perlintasan Sadewa } \\
\hline 1 & $\begin{array}{l}\text { Jumlah kereta api yang melintas pada lokasi } \\
\text { tersebut sebanyalk-banyalnyya } 25 \text { kereta hari; }\end{array}$ & $\begin{array}{l}\text { Jumlah kereta api yang melintas } \\
\text { sebanyak } 98 \text { kereta hari }\end{array}$ & $\times$ \\
\hline 2 & $\begin{array}{l}\text { Volume lalv lintas harian rata-rata (LHR) } \\
\text { sebanyalk-banyalknya } 1000 \text { kendaraan pada jalan } \\
\text { dalam kota dan } 300 \text { kendaraan pada jalan luar } \\
\text { kota }\end{array}$ & \begin{tabular}{|l|} 
Volume lalv lintas harian rata-rata \\
(LHR) sebesar $3145,995 \mathrm{smp} / \mathrm{jam}$
\end{tabular} & ' $x$ \\
\hline 3 & $\begin{array}{l}3 \text { Hasil perkalian antara volume lalv lintas harian } \\
\text { rata-rata (LHR) dengan fekvensi kereta api } \\
\text { sabanyalk-banyalnnya } 12.500 \text { smpk. }\end{array}$ & $\begin{array}{l}\text { Hasil perkalian antara volume latu } \\
\text { lintas harian rata- rata dengan felvensi } \\
\text { kereta api sebanyak } 308.879,5 \text { smpk }\end{array}$ & $\times$ \\
\hline
\end{tabular}

\section{b. Analisis Persyaratan Perlintasan Sebidang pada Perlintasan Sebidang Stasiun Jrakah}

\begin{tabular}{|c|c|c|c|}
\hline No & Persyaratan perlintasan sebidang & Perlintasan leereta api stasiun jralan & \\
\hline 1 & $\begin{array}{l}\text { Selang waktu antara kereta spi satu dengan kereta } \\
\text { spi berikutnya (Head way) yang melintas pada } \\
\text { lokasi tersabut rata-rata selurang-kurangnya } 6 \\
\text { (enam) menit pada waktu sibuk (peaḱ) }\end{array}$ & $\begin{array}{l}\text { Selang walkt antara kereta api satu } \\
\text { dengan kereta spi berikturnya (Head } \\
\text { way) yang melintas pada perlintasan } \\
\text { stasiun jrakah adalah } 7 \text { menit }\end{array}$ & $\sqrt{ }$ \\
\hline 2 & $\begin{array}{l}\text { Jarak pelintasan yang saru dengan yang lainnya } \\
\text { pada satu jalur kereta api tidak kurang dari } 800 \\
\text { meter; }\end{array}$ & $\begin{array}{l}\text { Jarak perlintasan terdekat adalah } 300 \\
\text { meter }\end{array}$ & ' $x$ \\
\hline 3 & $\begin{array}{l}\text { Tidak terletak pada lenghungan jalan kereta api } \\
\text { atav tikungan jalan; }\end{array}$ & Berada pada kondisi jalan lunvs & 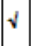 \\
\hline 4 & $\begin{array}{l}\text { Terdapat kondisi linghingan yang } \\
\text { memungkinkan pandangan bagi masinis kereta } \\
\text { api dari as perlintasan dan bagi pengemudi } \\
\text { kenderaan bermotor; }\end{array}$ & $\begin{array}{l}\text { Tidak ada bangunan atavoun pohon } \\
\text { yang menghalangi jarakt pandang } \\
\text { pengguna jalan }\end{array}$ & $\sqrt{2}$ \\
\hline 5 & Jalan yang melintas adalah jalan Kelas III & $\begin{array}{l}\text { Jalan stasiun jraktah termasuk ke dalam } \\
\text { kelas III }\end{array}$ & 4 \\
\hline
\end{tabular}

\begin{tabular}{|c|c|c|c|}
\hline No & Persyaratan prasarana jalan dan kereta api & $\begin{array}{l}\text { Prasarana jalan dan kereta api pad } \\
\text { perlintasan stasiuu jrakah }\end{array}$ & \\
\hline 1 & Jalan Kelas III & $\begin{array}{l}\text { Jalan stasiun jrakah termasuk ke dalam } \\
\text { kelas III }\end{array}$ & $\checkmark$ \\
\hline 2 & \begin{tabular}{|l|l|} 
Jalan sebanyal-banyaknya 2 lajur dua arah \\
\end{tabular} & Jalan terdiri deri 21 ajur 2 arah & $1 /$ \\
\hline 3 & $\begin{array}{l}\text { Tidak pada tikungan jalan dan/atas alinement } \\
\text { horizontal yang memiliki radivs sekurang- } \\
\text { kurangnva } 500 \mathrm{~m} \text { : }\end{array}$ & Berada pada kondisi jalan lurus & $\sqrt{ }$ \\
\hline 4 & $\begin{array}{l}\text { Tingkat kelandaian kurang dari } 5 \text { (lima) persen } \\
\text { dari titik terluar jalan rel: }\end{array}$ & Memiliki ketinggian yang sama & $\sqrt{ }$ \\
\hline 5 & Wajib dilengkapi Rambu peringatan & $\begin{array}{l}\text { Terdapat rambu peringatan } 22 \mathrm{a} \text { dan } \\
\text { rambu berupa kata-kata yang } \\
\text { menyatakan agar berhati-hati mendekati } \\
\text { perlintagan kereta spi }\end{array}$ & \\
\hline 6 & Wajib dilengkapi rambu larangan & Terdapat rambu andreas cross & ' $x$ \\
\hline 7 & $\begin{array}{l}\text { Wajib dilengkapi perlengkapan jalan berupa } \\
\text { marka jalan }\end{array}$ & Tidak terdapat marka jalan & ' \\
\hline 8 & $\begin{array}{l}\text { Wajib dilengkapi dengan isyarat lampu dan } \\
\text { suara }\end{array}$ & Terdapat isyarat lampu dan suara & $\sqrt{ }$ \\
\hline No & Penentuan Perlintasan Sebidang & Perlintasan stasiun jrakah & \\
\hline 1 & $\begin{array}{l}\text { Jumlah kereta spi yang melintas pada lokasi } \\
\text { tersebut sabanyalk-banyaknya } 25 \text { kereta hari; }\end{array}$ & $\begin{array}{l}\text { Jumlah kereta spi yang melintas } \\
\text { sebanyak } 86 \text { kereta hari }\end{array}$ & ' $x$ \\
\hline 2 & $\begin{array}{l}\text { Volume lalu lintas harian rata-rata (LHR) } \\
\text { sebanyalk-banyalknya } 1000 \text { kendaraan pada jalan } \\
\text { dalam kota dan } 300 \text { kendaraan pada jalan luar } \\
\text { kota }\end{array}$ & $\begin{array}{l}\text { Volume lalv lintas harian rata-rata } \\
\text { (LHR) sebesar } 2519,377 \mathrm{smp} \text { jam }\end{array}$ & ' \\
\hline & $\begin{array}{l}3 \text { Hasil petkalian antara volume latu lintas harian } \\
\text { rata-rata (LHR) dengan fekvensi kereta api } \\
\text { sebanyak-banyaknya } 12.500 \text { smpk. }\end{array}$ & $\begin{array}{l}\text { Hasil perkalian antara volume latu } \\
\text { lintas harian rata- rata dengan felvensi } \\
\text { kereta api sebanyak } 217.386 .2 \text { smpk }\end{array}$ & ' \\
\hline
\end{tabular}

\section{c. Analisis Persyaratan Perlintasan Sebidang pada Perlintasan Sebidang Jembawan Raya}

\begin{tabular}{|c|c|c|c|}
\hline No & Persyaratan perlintasan sebidang & Perlintasan lereta api jembawan & \\
\hline 1 & $\begin{array}{l}\text { Selang waktt antara kereta spi satu dengan kereta } \\
\text { api berikutnya (Head way) yang malintas pada } \\
\text { lokasi tersabut rata-rata selurang-kurangnya } 6 \\
\text { (enam) menit pada waktu sibuk (peak) }\end{array}$ & $\begin{array}{l}\text { Selang wakttu antara kereta api satv } \\
\text { dengan kereta api berikuthya (Head } \\
\text { way) yang melintas pada perlintasan } \\
\text { stasivn jrakah adalah } 7 \text { menit }\end{array}$ & $\sqrt{ }$ \\
\hline 2 & $\begin{array}{l}\text { Jarak perlintasan yang satu dengan yang lainnya } \\
\text { pada satu jalur kereta api tidak kurang dari } 800 \\
\text { meter; }\end{array}$ & $\begin{array}{l}\text { Jarak perlintasan terdekat adalah } 650 \\
\text { mater }\end{array}$ & $x$ \\
\hline 3 & $\begin{array}{l}\text { Tidak terletak pada lenghungan jalan kereta api } \\
\text { atav tikungan jalan; }\end{array}$ & Berada pada kondisi jalan lunus & $\sqrt{ }$ \\
\hline 4 & $\begin{array}{l}\text { Terdapat kondisi linglungan yang } \\
\text { memungkinkan pandangan bagi masinis kereta } \\
\text { api dari as perlintasan dan bagi pengemvdi } \\
\text { kendaraan bermotor; }\end{array}$ & $\begin{array}{l}\text { Ada pohon yang menghalangi jarak } \\
\text { pandang pengguna jalan }\end{array}$ & $\times$ \\
\hline 5 & Jalan yang melintas adalah jalan Kelas III & $\begin{array}{l}\text { Jalan jembarwan raya termasuk ke } \\
\text { dalam kelas III }\end{array}$ & $\sqrt{ }$ \\
\hline
\end{tabular}

\begin{tabular}{|c|c|c|c|}
\hline No & Persyaratan prasarana jalan dan kereta api & $\begin{array}{c}\text { Prasarana jalan dan kereta api pada } \\
\text { perlintasan jembawan raya }\end{array}$ & \\
\hline 1 & Jalan Kelas III & $\begin{array}{l}\text { Jalan Jembarwan Raya termasuk ke } \\
\text { dalam kelas III }\end{array}$ & $\sqrt{1}$ \\
\hline 2 & Jalan sebanyalk-banyalknya 2 lajur dua arah & Jalan terdiri dari 2 lajur 2 arah & $\sqrt{ }$ \\
\hline 3 & $\begin{array}{l}\text { Tidak pada tikungan jalan dan/atav alinement } \\
\text { horizontal yang memiliki radivs salurang- } \\
\text { kurangnya } 500 \mathrm{~m} \text { : }\end{array}$ & Berada pada kondisi jalan lurus & $\checkmark$ \\
\hline 4 & $\begin{array}{l}\text { Tinglkat kelandaian kurang dari } 5 \text { (lima) persen } \\
\text { dari titik terluar ialan rel: }\end{array}$ & Memiliki ketinggian yang berbada & $\checkmark$ \\
\hline 5 & Wajib ditengkapi Rambu peringatan & $\begin{array}{|lll|}\text { Terdapat rambu peringatan } & 22 \mathrm{a} \text { dan } \\
\text { rambu } & \text { berupa } & \text { kata-kata yang } \\
\text { menyatakan agar berhati-hati mendekati } \\
\text { perlintasan kereta api }\end{array}$ & $x$ \\
\hline 6 & Wajib dilenghapi rambu larangan & Terdapat rambu andreas Cross & $\mathbf{x}$ \\
\hline 7 & $\begin{array}{l}\text { Wajib dilengkapi perlengkapan jalan berupa } \\
\text { marka jalan }\end{array}$ & Tidak terdapat marka jalan & 'x \\
\hline 8 & $\begin{array}{l}\text { Wajib dilengkapi dengan isyarat lampu dan } \\
\text { suara }\end{array}$ & Terdapat isyarat lampu dan suara & $\sqrt{ }$ \\
\hline
\end{tabular}




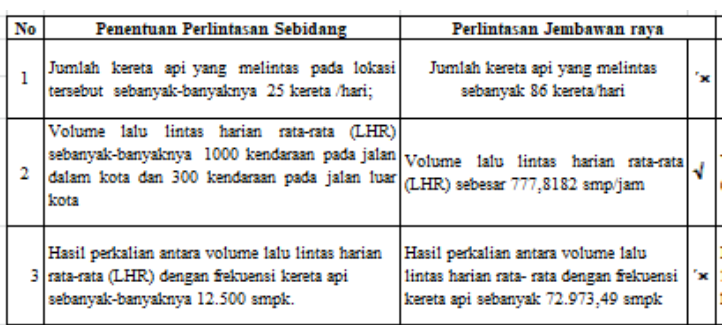

d. Jarak Pandang

\begin{tabular}{|l|c|c|c|c|c|c|c|c|c|c|}
\hline Perlintasan & $\begin{array}{c}\text { Vv } \\
(\mathbf{k m} \\
\text { jam }\end{array}$ & $\begin{array}{c}\mathbf{t} \\
(\mathbf{d e t})\end{array}$ & $\begin{array}{c}\mathbf{D} \\
(\mathbf{m})\end{array}$ & $\mathbf{d c}(\mathbf{m})$ & $\mathbf{f}$ & $\begin{array}{c}\mathbf{V t}(\mathbf{k m} \\
\text { /jam })\end{array}$ & $\mathbf{L}(\mathbf{m})$ & $\mathbf{W}(\mathbf{m})$ & $\begin{array}{c}\mathbf{d H} \\
(\mathbf{m})\end{array}$ & $\mathbf{d T ( m )}$ \\
\hline $\begin{array}{l}\text { Sadewa } \\
\text { Stasiun } \\
\text { Irakah }\end{array}$ & 20 & 2,5 & 4,5 & 3 & 0,19 & 60 & 20 & 3 & 16,62 & 246,73 \\
\hline $\begin{array}{l}\text { Jembawan } \\
\text { Raya }\end{array}$ & 20 & 2,5 & 4,5 & 3 & 0,18 & 60 & 20 & 3 & 30,30 & 164,39 \\
\hline
\end{tabular}

e. Hubungan Antara Tundaan dan Panjang Antrian Terhadap Kapasitas Jalan

\begin{tabular}{|c|c|c|c|c|c|c|}
\hline \multirow{2}{*}{ Perlintasan } & \multirow{2}{*}{\multicolumn{2}{|c|}{ C(smp/jam) }} & \multicolumn{4}{|c|}{ Eksisting } \\
\hline & & & Tundaan (det) & \multicolumn{2}{|c|}{ Panjang antrian (smp) } & DS \\
\hline Sadewa & \multicolumn{2}{|c|}{1015,00} & 39,24 & \multirow{2}{*}{\multicolumn{2}{|c|}{$\begin{array}{l}5,61 \\
3,95\end{array}$}} & 0,006 \\
\hline Stasiun Jrakah & \multicolumn{2}{|c|}{1131,00} & 22,15 & & & 0,003 \\
\hline Jembawan Raya & \multicolumn{2}{|c|}{1276,00} & 22,32 & \multicolumn{2}{|c|}{1,30} & 0,001 \\
\hline \multicolumn{7}{|c|}{ Pertumbuhan 2 tahun } \\
\hline \multicolumn{2}{|c|}{ Tundaan (det) } & \multicolumn{3}{|c|}{ Panjang antrian (smp) } & \multicolumn{2}{|c|}{ DS } \\
\hline \multicolumn{2}{|l|}{46,35} & \multicolumn{3}{|c|}{6,63} & \multicolumn{2}{|c|}{0,007} \\
\hline \multicolumn{2}{|l|}{26,17} & \multicolumn{3}{|c|}{4,67} & \multicolumn{2}{|c|}{0,004} \\
\hline 26,37 & & \multicolumn{3}{|c|}{1,54} & \multicolumn{2}{|c|}{0,001} \\
\hline \multicolumn{7}{|c|}{ Pertumbuhan 5 tahun } \\
\hline \multicolumn{2}{|c|}{ Tundaan (det) } & \multicolumn{3}{|c|}{ Panjang antrian (smp) } & \multicolumn{2}{|c|}{ DS } \\
\hline \multicolumn{2}{|c|}{54,76} & \multicolumn{3}{|c|}{7,83} & \multicolumn{2}{|c|}{0,008} \\
\hline \multicolumn{2}{|c|}{30,91} & \multicolumn{3}{|c|}{5,51} & \multicolumn{2}{|c|}{0,005} \\
\hline \multicolumn{2}{|c|}{31,15} & \multicolumn{3}{|c|}{1,81} & \multicolumn{2}{|c|}{0,001} \\
\hline
\end{tabular}

\begin{tabular}{|c|c|c|}
\hline \multicolumn{3}{|c|}{ Pertumbuhan 10 tahun } \\
\hline Tundaan (det) & Panjang antrian (smp) & DS \\
\hline 64,68 & 9,25 & 0,009 \\
\hline 36,51 & 6,51 & 0,006 \\
\hline 36,79 & 2,14 & 0,002 \\
\hline
\end{tabular}

f. Hubungan Antara Volume, Kapasitas dan Derajat Kejenuhan

\begin{tabular}{c|c|c|c|c|c|c|}
\hline Perlintasan & $\mathbf{V}($ smp/jam) & $\begin{array}{c}\mathbf{C} \\
\text { (smp/jam) }\end{array}$ & DS & Kereta & $\begin{array}{c}\text { VxKereta } \\
\text { (smpk) }\end{array}$ & LOS \\
\hline Sadewa & 3145,99 & 1015 & 3,10 & 98 & 308307,49 & $\mathrm{~F}$ \\
\hline $\begin{array}{c}\text { Stasiun } \\
\text { Jrakah }\end{array}$ & 2519,38 & 1131 & 2,22 & 86 & 216666,39 & $\mathrm{~F}$ \\
\hline $\begin{array}{c}\text { Jembawan } \\
\text { Raya }\end{array}$ & 777,94 & 1276 & 0,61 & 86 & 66903,309 & $\mathrm{C}$ \\
\hline
\end{tabular}

g. Forecasting Pada Perlintasan Sadewa, Stasiun Jrakah dan Jembawan Raya

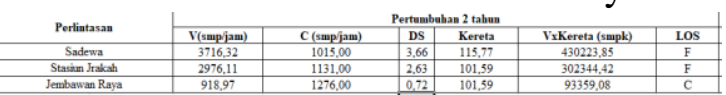

\begin{tabular}{c|c|c|c|c|c|}
\multicolumn{7}{c|}{ Pertumbuhan 5 tahun } \\
\hline V(smp/jam) & C (smp/jam) & DS & Kereta & VxKereta (smpk) & LOS \\
\hline 3644,62 & 1015,00 & 3,59 & 171,77 & 626023,06 & F \\
\hline 2918,68 & 1131,00 & 2,58 & 150,73 & 439944,41 & F \\
\hline 901,24 & 1276,00 & 0,71 & 150,73 & 135847,74 & C \\
\hline \multicolumn{7}{|c|}{ Pertumbuhan 10 tahun } \\
\hline V(smp/jam) & C (smp/jam) & DS & Kereta & VxKereta (smpk) & LOS \\
\hline 4430,23 & 1015,00 & 4,36 & 348,39 & 1543459,21 & F \\
\hline 3547,82 & 1131,00 & 3,14 & 305,73 & 1084682,48 & F \\
\hline 1095,51 & 1276,00 & 0,86 & 305,73 & 334932,45 & E \\
\hline
\end{tabular}

\section{Simulasi dengan Menggunakan PTV Vissim 9.0}

Pemodelan simulasi dengan menggunakan PTV Vissim 9.0 dilakukan setelah data volume kendaraan, kecepatan kereta, didapatkan. Proses simulasi ini akan menghasilkan bentuk simulasi kondisi lapangan di perlintasan saa ini maupun setelahfly over dipasang.

a. Simulasi Pada Perlintasan Sadewa

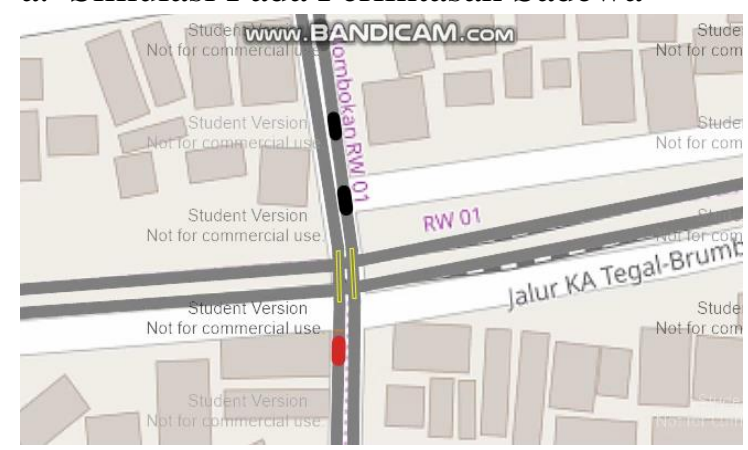

Gambar 4.11 perlintasan sebidang sadewa (Sumber : Hasil Analisis, 2018)

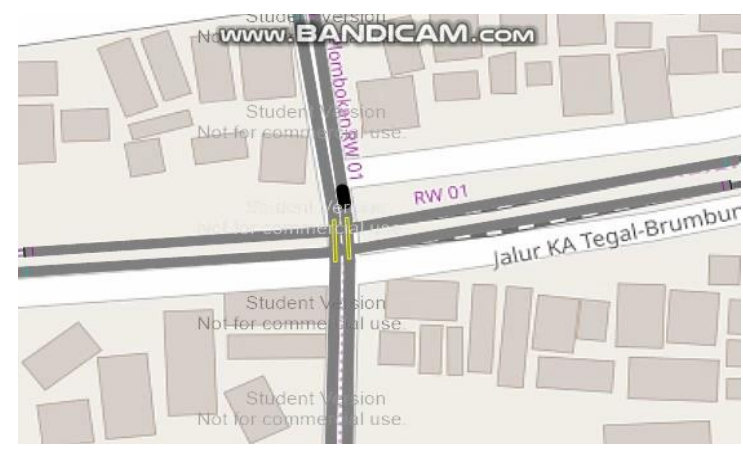

Gambar 4.12 perlintasan tidak sebidang sadewa

(Sumber : Hasil Analisis,2018) 
b. Simulasi Pada Perlintasan stasiun

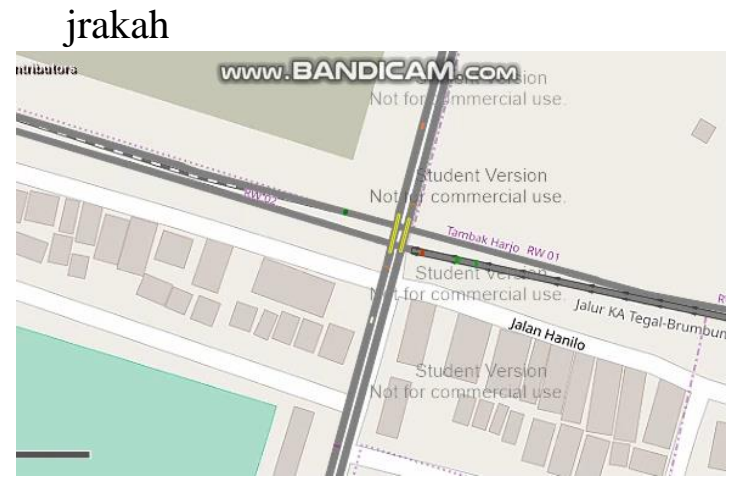

Gambar 4.13 perlintasan sebidang Jrakah

(Sumber : Hasil Analisis,2018)

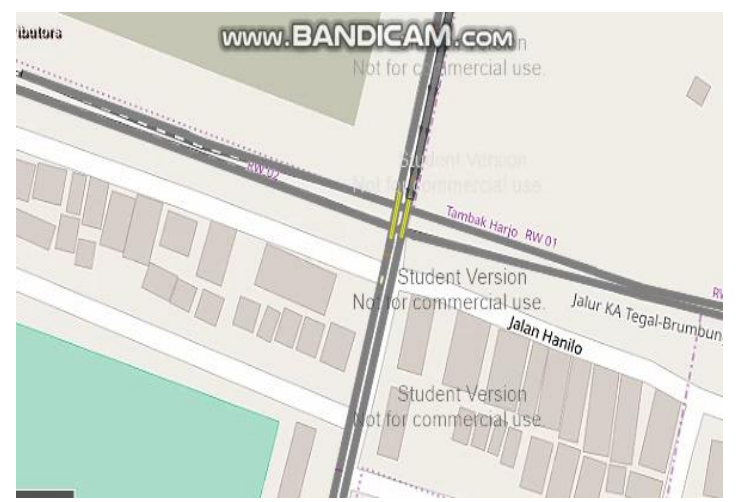

Gambar 4.14 perlintasan tidak sebidang Jrakah

(Sumber : Hasil Analisis, 2018)

c. Simulasi Pada Perlintasan Jembawan Raya

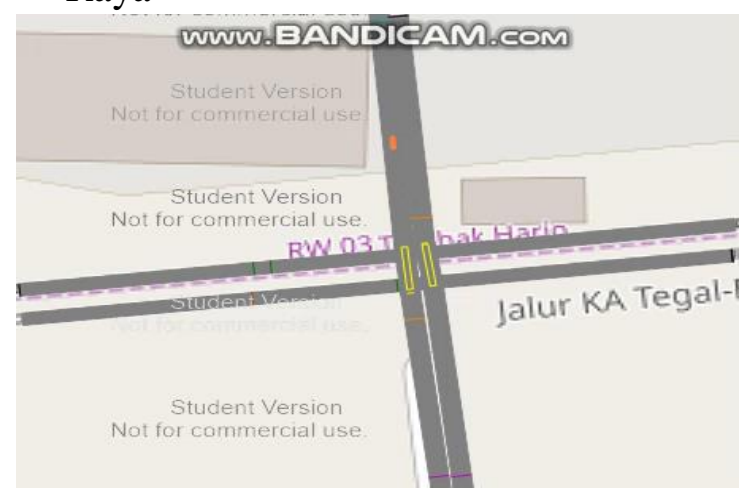

Gambar 4.15 perlintasan sebidang Jembawan Raya

(Sumber : Hasil Analisis,2018)

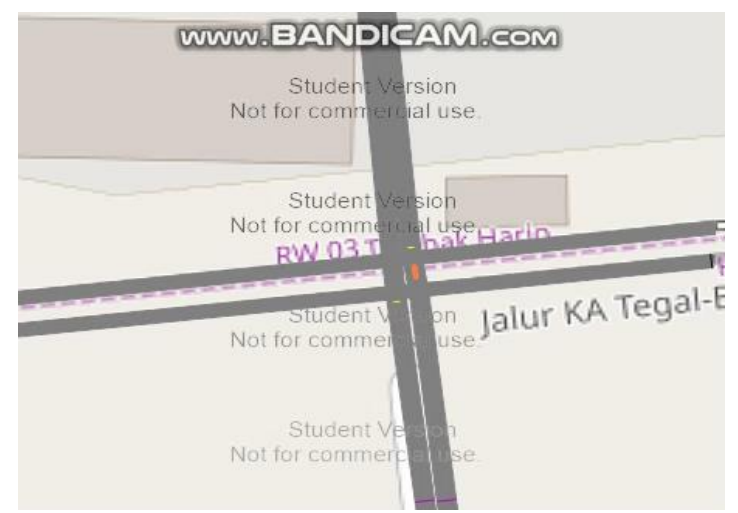

Gambar 4.16 perlintasan sebidang Jembawan Raya

(Sumber : Hasil Analisis,2018)

\section{PENUTUP}

\subsection{Kesimpulan}

1. Analisis panjang antrian dan tundaan pada perlintasan Sadewa, Perlintasan stasiun jrakah dan perlintasan Jembawan Raya berdasarkan kapasitas jalan kendaraan yang tertunda pada saat kereta api melintas masih mencukupi ruas jalan yang ada.

2. Berdasarkan analisis persyaratan perlintasan sebidang sesuai dengan SK 770 tahun 2005, perlintasan sadewa dan perlintasan stasiun jrakah memenuhi 4 dari 5 syarat dan perlinatsan jembawan raya memenuhi 3 dari 5 syarat.

3. Berdasarkan analisis persyaratan prasarana jalan dan kereta api sesuai dengan SK 770 tahun 2005, perlintasan sadewa,perlintasan stasiun jrakah dan perlinatsan jembawan raya memenuhi 5 dari 8 syarat.

4. Berdasarkan analisis penentuan perlintasan sebidang tanpa pintu sesuai dengan SK 770 tahun 2005, perlintasan sadewa dan perlintasan stasiun jrakah tidak memenuhi 
semua syarat dan perlinatsan jembawan raya memenuhi 1 dari 3 syarat.

5. Berdasarkan ketentuan pada SK 770 tahun 2005, perlintasan sadewa (308.307,49 smpk), stasiun jrakah (216.666,39 smpk) dan jembawan raya $(66.903,09 \mathrm{smpk})$ sudah tidak memenuhi syarat sebagai perlintasan sebidang ( LHR x Frekuensi kereta api < 35.000 smpk), sehingga sebaiknya sudah ditingkatkan menjadi perlintasan tidak sebidang.

6. Meskipun berdasarkan perhitungan forecasting 2,5 dan 10 tahun ke depan panjang antrian yang terjadi pada perlintasan sadewa, stasiun jrakah dan jembawan raya masih memenuhi syarat kapasitas jalan yang tersedia. Namun, berdasarkan perhitungan forecasting volume, kapasitas jalan pada perlintasan sadewa dan stasiun jrakah sudah tidak sanggup menampung lalulintas harian rata-rata sehingga perlu dilakukan peninjauan ulang terhadap kondisi jalan di perlintasan tersebut.

\subsection{Saran}

1. Perlintasan Sebidang Sadewa, Perlintasan stasiun jrakah dan perlintasan Jembawan Raya sebaiknya ditingkatkan menjadi perlintasan tidak sebidang.

2. Perlunya penambahan rambu larangan serta rambu peringatan sesuai SK 770 tahun 2005 pada Perlintasan Sadewa, Perlintasan stasiun jrakah dan Perlintasan Jembawan Raya.

3. Perlu pemasangan marka jalan pada Perlintasan Sadewa, Perlintasan stasiun jrakah dan Perlintasan Jembawan Raya.

4. Perlu dilakukan peninjauan ulang terhadap kondisi jalan pada
Perlintasan Sadewa dan Perlintasan stasiun jrakah.

5. Penentuan pembuatan perlintasan tidaksebidang berupa flyover maupun underpass membutuhkan penelitian lebih lanjut.

\section{DAFTAR PUSTAKA}

Caisarina, I.,Isya, M., danAriadi (2016): Analisis hubungan antara volume, kecepatan dan kepadatan lalu lintas, Jurnal Teknik Sipil Universitas Syiah Kuala, Vol 5 No. 3

Dewi, Z.S danRizki, M.A (2014): Evaluasi pergerakan arus lalu lintas di dalam kampus universitas brawijaya malang TugasAkhir

Program StudiTeknikSipil, Universitas Brawijaya

Dhijayanti, A. (2012): Faktor-Faktor yang mempengaruhi tingkat aksesibilitas di pelrintasan kereta api kota surakarta, TugasAkhir Program Studi Perencanaan Wilayah dan Kota, UniversitasSebelas Maret

Data Geometri jalan diperoleh dari situs internet:

http://jalanpu.semarangkota.go.id/.

Diunduh pada 3 September 2018 pukul 19.00 WIB

1999, Rekayasa Lalu Lintas,Direktorat Bina Sistem Lalu Lintas dan angkutan Kota, Direktorat Jenderal Perhubungan Darat, Jakarta.

Hobbs, F.D, (1995): Perencanaan dan Teknik Lalu Lintas, Penerbit Gadjah Mada 
Emzir. 2007. Metodologi Penelitian Pendidikan Kuantitatif dan Kualitatif. Jakarta : PT Raja Grafindo Persada , 1997, Manual Kapasitas Jalan Indonesia, Direktorat Jenderal

Bina Marga, Departemen Pekerjaan Umum, Jakarta.

Nahdaina danWinarsih, N. (2017): Analisis antrian dan tundaan akibat lampu lalu lintas dan penutupan pintu perlintasan kereta api menggunakan metode antrian deterinistik, Jurnal Desain Konstruksi, Vol 16 No.1

Narimawati, Umi. 2008. Metodologi Penelitian Kuatitatif dan Kualitatif, Teori dan Aplikasi. Bandung: Agung Media

Novandi, E.R. (2010): Studi manajemen perlintasan sebidang alan raya dengan jalan kereta api, TugasAkhir Program StudiTeknikSipil, Universitas Sumatera Utara

Peraturan Menteri 10 tahun 2011 tentang persyaratan teknis peralatan persinyalan

PeraturanPemerintah No. 43 tahun 1993 tentangPrasaranadanlalu lintasjalan

Peraturan Pemerintah No.56 tahun 2009 tentang penyelenggaraan perkeretaapian

Putra, E.W (2009): Studi keselamtan dan keamanan transportasi di perlintasan sebidang antara jalan rel dengan jalan umum, TugasAkhir Program StudiTeknikSipil, Universitas Negeri Semarang
Ruslan, Rosady. 2003. Metode Penelitian PR dan Komunikasi. Jakarta: PT Raja Grafindo Persada

SK.770/KA.401/DRJD/2005, (2005), "PeraturanDirekturJenderalPerhubun ganDaratNomortentangPedomanTek nisPerlintasanSebidangAntaraJalande nganJalurKeretaApi"

Soejachmoen, K.(2004). Keselamatan pejalan kaki dan transportasi.

Transportation Research Board. (1994): Highway Capacity Manual Special Report 209. Washington, D.C.

Undang-Undang No. 23 Tahun 2007 tentang perkeretaapian

Undang-Undang No. 22 Tahun 2009 tentang Lalu Lintas dan Angkutan Jalan

Wildan. (2013): Kajian keselamatan jalan pada persilangan sebidang jalan dengan kereta api, Thesis Program Pasca Sarjana Magister Teknik Sipil, Universitas Islam Sultan Agung. 